\title{
Differential Nephrotoxicity of Low Molecular Weight Proteins Including Bence Jones Proteins in the Perfused Rat Nephron In Vivo
}

\author{
Paul W. Sanders, Guillermo A. Herrera, Ann Chen, Beverly B. Booker, and John H. Galla \\ with the technical assistance of James R. Hancock and Robert Lott \\ Nephrology Research and Training Center and Division of Nephrology, Department of Medicine, and Department of Pathology, \\ University of Alabama at Birmingham, and Veterans Administration Medical Center, Birmingham, Alabama 35294
}

\begin{abstract}
To investigate the pathogenetic mechanisms of tubule nephrotoxicity of low molecular weight proteins (LMWP), proximal tubules (PT) of rats were perfused in vivo with artificial tubule fluid (ATF) containing one of five LMWPs: three human Bence Jones proteins (BJP), $\beta$-lactoglobulin (BLG), and rabbit myoglobin (MYG). Volume $\left(J_{v}\right)$, chloride $\left(J_{C l}\right)$ and glucose $\left(J_{G}\right)$ fluxes in these perfused PTs were compared with those determined using ATF alone. In separate experiments, perfused nephrons were examined with electron and immunoelectron microscopy. After exposure to BJPi or BLG, $J_{v}, J_{C l}$, and $J_{G}$ were less $(P<0.05)$ than corresponding control fluxes. Cell damage of these perfused PTs, along with cellular debris in the distal tubules, was prominent. The PT lysosomes often appeared atypical and contained crystals. In contrast, perfusion with BJP2, BJP3, or MYG did not alter $J_{v}, J_{C l}$, or $J_{G}$. These findings were corroborated by the normal ultrastructure of these PTs despite immunohistochemical evidence of endocytosis of the BJPs. Isoelectric point, molecular form, and isotype were not factors associated with PT damage. In addition, proteins with $\mathrm{pI}<\mathbf{7 . 4}$ precipitated in the distal nephron, forming acellular casts.

Thus, certain nephrotoxic LMWPs damaged the PT, while others precipitated in the distal tubule, obstructing the nephron. These two pathogenetic mechanisms may independently be responsible for tubulointerstitial nephropathy of LMWPs in humans.
\end{abstract}

\section{Introduction}

Low molecular weight proteins (LMWP) ${ }^{1}$ are filtered and subsequently reabsorbed by the epithelium of the proximal tubule

Presented at the Annual Meeting of the American Federation for Clinical Research and the American Society of Nephrology and the 5th International Symposium of Nephrology at Montecatini Terme and have been published in abstract form in 1987 (Clin. Res. 35: 556a) and 1988 (Kidney Int. 33:365).

Address reprint requests to Dr. Sanders, Nephrology Research and Training Center, University of Alabama at Birmingham, Birmingham, AL 35294.

Received for publication 10 February 1988 and in revised form 25 July 1988

1. Abbreviations used in this paper: ATF, artificial tubule fluid; BJP, Bence Jones protein; BLG, $\beta$-lactoglobulin; BW, body weight; LC, light chain; LMWP, low molecular weight protein; MYG, myoglobin; PT, proximal tubule; TBS, Tris-buffered saline.

J. Clin. Invest.

(C) The American Society for Clinical Investigation, Inc.

$0021-9738 / 88 / 12 / 2086 / 11 \quad \$ 2.00$

Volume 82, December 1988, 2086-2096
(PT), where they are usually hydrolyzed with return of their amino acid components to the circulation across the basolateral membrane $(1,2)$. Although this process occurs for a variety of LMWPs, we have shown that reabsorption of human Bence Jones protein (BJP) can result in accumulation of this LMWP in the endolysosomal system of human PT cells and is associated with cell damage (3). We have translated this lesion to a rat model in which, in addition to lysosomal overload, a time-dependent functional and structural injury of PT epithelium was shown after $20 \mathrm{~min}$ of exposure to a human BJP in vivo (4). The morphologic alterations and sites of BJP deposition in the cells of the BJP-perfused PTs were identical to those of the epithelium of human PTs exposed to BJPs. With this in vivo rat model of direct cellular toxicity and morphologic evaluation of the perfused nephrons, the purpose of this study was to characterize the mechanisms of nephrotoxicity of five unique LMWPs in the rat nephron, correlating these pathogenetic mechanisms with the physicochemical characteristics of the proteins.

\section{Methods}

Animal preparation. The preparation for micropuncture was similar to the method described previously (5). Male Sprague-Dawley rats (Charles River Breeding Laboratories, Inc., Wilmington, MA, or Taconic Farms, Inc., Germantown, NY), which weighed 220-325 g $(285 \pm 2 \mathrm{~g})$ and were maintained on standard rat chow (Agway/Prolab 1000 , Syracuse, NY) and tap water ad lib., were anesthetized with ethyl, 1-methylpropylthiobarbiturate (Inactin; BYK Gulden, FRG), $100 \mathrm{mg} / \mathrm{kg}$ body weight (BW) i.p. After placement on a servo-controlled heated table, tracheostomy and cannulation of the right external jugular vein were performed, followed by infusion of Ringer-bicarbonate with $2 \%$ polyfructosan (Inutest; Laevosan-Gesellschaft, Linz, Austria) at $2.0 \mathrm{ml} / 100 \mathrm{~g} \mathrm{BW} / \mathrm{h}$ after a $1-\mathrm{ml}$ bolus. The right femoral artery was cannulated to monitor arterial pressure and to sample blood. The bladder was catheterized through a suprapubic route for urine collections. The left kidney was exposed through a subcostal incision and, after separation from the perirenal fat and adjacent adrenal gland, was placed in a Lucite cup. A well was formed on the surface of the kidney with $4 \%$ agar and was filled with water-equilibrated, warmed mineral oil.

Microperfusion protocol. The microperfusion protocol has been described in detail previously (4). Approximately $1 \mathrm{~h}$ after the intravenous infusion was started, arterial blood samples were collected for the determination of hematocrit, osmolality, and plasma sodium, potassium, chloride, and protein concentrations. The micropuncture period was then begun. A pipette filled with an artificial tubule fluid (ATF) was inserted into an early surface proximal convoluted tubule segment and a small bolus of tinted fluid outlined the nephron. The ATF contained (in mM): $95 \mathrm{NaCl}, 25 \mathrm{NaHCO}_{3}, 5 \mathrm{KCl}, 0.6 \mathrm{CaCl}_{2}, 3.1$ $\mathrm{NaH}_{2} \mathrm{PO}_{4}, 6 \mathrm{Na}_{2} \mathrm{HPO}_{4}, 7.5$ D-glucose, 4.5 urea; this fluid was tinted with Food, Drug and Cosmetic (FD\&C) Green \#3 (Keystone Aniline and Chemical Co., Chicago, IL). A pipette filled with bone wax was 
inserted into the earliest accessible surface proximal convolution and a small cast 4-5 tubule diameters in length was injected into the tubule with a microdrive unit (Trent Wells, South Gate, CA). A pipette attached to a microperfusion pump (W-P Instruments, Inc., New Haven, CT) was inserted into the tubule just distal to the wax block and the remaining nephron was perfused at $20 \mathrm{nl} / \mathrm{min}$. The composition of the perfusion solutions was the same as described above except for the addition of $\left[{ }^{3} \mathrm{H}\right]$ methoxyinulin $(269.5 \mathrm{mCi} / \mathrm{g}$; New England Nuclear, Boston, MA), which had been extensively dialyzed against distilled water, and a trace amount of $\mathrm{D}-\left[{ }^{14} \mathrm{C}\right]$ glucose $(257.7 \mathrm{mCi} / \mathrm{mmol}$; New England Nuclear). The final $\mathrm{pH}$ of each perfusion solution was adjusted to 7.40 by bubbling a mixture of $95 \% \mathrm{O}_{2} / 5 \% \mathrm{CO}_{2}$ into the solution just before aspiration of the fluid into the perfusion pipette. After perfusion of the tubule for $20 \mathrm{~min}$, a collection pipette filled with tinted mineral oil was inserted into the latest accessible surface proximal convolution, a mineral oil block was injected, and a complete timed collection of tubule fluid was made for $\sim 3 \mathrm{~min}$. We perfused the maximum available length of surface proximal convoluted tubule. After the collections were complete, the perfused segments were injected with Microfil (Canton Bio-Medical Products, Inc., Boulder, $\mathrm{CO}$ ) and the kidney was removed and dissolved in $25 \% \mathrm{NaOH}$. The perfused segments were later dissected and their lengths measured directly with a micrometer scale.

The effects of the presence of five test LMWPs were studied by adding them to ATF at $5 \mathrm{~g} / \mathrm{dl}$. Experimental perfusions were compared to corresponding, contemporaneously obtained, control (ATF) perfusions that used ATF alone. Experimental and ATF perfusions were performed in each rat. Three of the LMWPs were human Bence Jones proteins (BJP1, 2, and 3) $2 \kappa, 1 \lambda$, that were purified, as described below, from the urine of patients who had multiple myeloma and renal failure. BJP1, which has been shown to be toxic (4), was also used to determine a "dose-response" of the functional indices of toxicity. $\beta$ lactoglobulin (BLG) has been shown to produce acute renal failure in rats (6) and rabbit myoglobin (MYG) (both from Diversified Biotech, Newton Centre, MA) has exhibited nephrotoxicity under certain conditions $(6,7)$.

During the microperfusion period, two 30-min inulin clearances were determined and, at the completion of micropuncture, arterial blood was sampled for determination of hematocrit, osmolality, and plasma sodium, potassium, chloride, protein, and glucose concentrations. Rats were considered unsuitable for study if the arterial pressure fell below $100 \mathrm{mmHg}$ or if the inulin clearance was $<500 \mu \mathrm{l} / \mathrm{min}$ per $100 \mathrm{~g} \mathrm{BW}$. Tubule perfusions were accepted for study if they had calculated perfusion rates between 16 and $23 \mathrm{nl} / \mathrm{min}$, collectate to perfusate inulin ratios $\geq 1.0$, and perfused tubule lengths between 0.7 and $4.0 \mathrm{~mm}$. Requiring that the collectate to perfusate inulin ratio be $\geq 1.0$ was necessary because, although it underestimated the nephrotoxic potential of the LMWPs, technical artifact could also have produced the same result (i.e., a ratio $<1.0$ ).

Morphologic and immunocytochemical studies. Histologic examination of individual in vivo perfused nephrons was performed using previously described techniques $(3,4)$. In these experiments, a single inulin clearance and packed cell volume were collected during the microperfusion period. The perfusates were similar to those used in the microperfusion experiments except for omission of the $\left[{ }^{3} \mathrm{H}\right]$ methoxyinulin and $\mathrm{D}-\left[{ }^{14} \mathrm{C}\right]$ glucose. After perfusion of the nephron distal to the wax block with the perfusate for $20 \mathrm{~min}$, the tubules were reperfused immediately for 3-4 min with FD\&C tinted, Carson-Millonig's solution, $\mathrm{pH} 7.0$, that contained gold particles (Janssen Pharmaceutica N.V., Beerse, Belgium) which served as markers for ultrastructural identification of the perfused tubule. The rat was killed and the tubules carefully dissected and placed in untinted Carson-Millonig's solution, $\mathrm{pH} 7.0$, until preparation for electron microscopy. After initial fixation, the specimens were washed briefly in Tris buffer, pH 7.6, and were blotted. They were then processed through several solutions of increasing concentrations of ethyl alcohol: $15 \mathrm{~min}$ in $60 \%$, $15 \mathrm{~min}$ in $80 \%$, and $20 \mathrm{~min}$ in $95 \%$ (two exchanges). In order to avoid excessive shrinkage, the tissues were also incubated in a 2:1 mixture of
L.R. White resin (Polysciences Inc., Warrington, PA)/95\% ethanol for $1 \mathrm{~h}$ at room temperature. After these procedures, the specimens were blotted and infiltrated with pure L.R. White resin overnight at $4^{\circ} \mathrm{C}$. The tissues were then incubated for $1 \mathrm{~h}$ in fresh resin, allowing further infiltration into the tissues, and the resin was polymerized over 18-24 $\mathrm{h}$ at $50^{\circ} \mathrm{C}$ (temperatures greater then $60^{\circ} \mathrm{C}$ were avoided). The embedded specimens were further trimmed to facilitate identification of the perfused nephron. Thick sections of the plastic-embedded material were stained with toluidine blue (Fisher Scientific Co., Fair Lawn, NJ) for light microscopy survey and identification of the perfused tubule. Ultrathin sections were postcontrasted with uranyl acetate and lead citrate (Fisher Scientific Co.). The specimens were examined with a transmission electron microscope (model H-600; Nissei Sangyo America, Ltd., Hitachi Scientific Instruments, Tokyo, Japan).

Those specimens that were exposed to the BJPs were also processed for immunoelectron microscopy using an indirect immunogold staining procedure $(3,4,8)$. Ultrathin sections were cut from the block and collected on uncoated 300 mesh nickel grids (Electron Microscopy Sciences, Fort Washington, PA) and dried overnight at room temperature. Grid-mounted sections were incubated at room temperature in normal goat serum (Vector Laboratories, Inc., Burlingame, CA), 1:30 dilution in $0.05 \mathrm{M}$ Tris-buffered saline (TBS), for $30 \mathrm{~min}$. The grids were then incubated with polyclonal antibodies to $\kappa$ and $\lambda$ light chains (Dakopatts, Accurate Chemical and Scientific Corp., Westbury, NY), 1:1,000 and 1:2,000 dilutions in TBS, for $16 \mathrm{~h}$ at $4^{\circ} \mathrm{C}$, and then washed twice in TBS and once in TBS that contained 1\% BSA, 10 min each. The grids were then incubated for $1 \mathrm{~h}$ at room temperature in gold-labeled goat anti-rabbit IgG serum (Janssen Pharmaceutica N.V.), 1/15 in $0.02 \mathrm{M}$ TBS containing $1 \% \mathrm{BSA}, \mathrm{pH}$ 8.2. The samples were again washed twice in TBS and twice in distilled water, 10 min each. The sections were counterstained with uranyl acetate and lead citrate.

Protein preparation and analysis. The BJPs were isolated from the urine of patients using previously described techniques (4) that included ammonium sulfate precipitation, ion exchange chromatography, and extensive dialysis. Immunoelectrophoresis as described in LKB Application Note 249 confirmed the isotype of the BJP using monoclonal and polyclonal antibodies to human $\kappa$ and $\lambda$ LCs (Calbiochem-Behring Diagnostics, La Jolla, CA).

Purity, molecular forms, and molecular weights of the proteins were determined in triplicate by electrophoresis at $5^{\circ} \mathrm{C}$ on horizontal $10-20 \%$ polyacrylamide gradient slab gels containing $0.1 \%$ SDSPAGE, as described in LKB Application Note 320 and by Görg et al. (9); both reducing and nonreducing conditions were utilized. The apparent molecular weights were derived from a standard curve constructed with molecular weights assigned to the following proteins: cytochrome $c(12,300 \mathrm{D})$, equine myoglobin $(17,200)$, carbonic anhydrase $(30,000)$, ovalbumin $(45,000)$, BSA $(66,250)$, and ovotransferrin $(78,000)$ (LKB-Produktor AB, Bromma, Sweden). Analysis of the molecular forms was performed with a GS 300 scanning densitometer (Hoefer Scientific Instruments, San Francisco, CA). Gel filtration chromatography was performed with a fraction collector (2112 Redirac; LKB-Produktor AB), a peristaltic pump (2232 MicroPerpex S Pump; LKB-Produktor AB), and a $2.6 \times 45 \mathrm{~cm}$ column that was filled with Sephacryl S-200 Superfine media (Pharmacia AB, Uppsala, Sweden); the eluate was monitored with an ultraviolet detector (2138 Uvicord S; LKB-Produktor $\mathrm{AB}$ ) and a potentiometric recorder (2210; LKB-Produktor AB). The column was calibrated with proteins of known molecular weights and included ribonuclease $A(13,700 \mathrm{D})$, chymotrypsinogen A $(25,000)$, ovalbumin $(43,000)$, BSA $(67,000)$, aldolase $(158,000)$, catalase $(232,000)$, and thyroglobulin $(669,000)$.

The isoelectric points (pI) of the proteins were determined in triplicate at $10^{\circ} \mathrm{C}$ using standard techniques, described in the LKB Application Note 250, with Ampholine PAGplates, pH 3.5-9.5, and pI marker proteins (both from LKB-Produktor AB). Protein bands were identified with $1 \%$ Coomassie Blue (LKB-Produktor AB).

Analytical methods. The methods for determination of inulin clearance, hematocrit, and plasma sodium, potassium, chloride, osmolality, protein, and glucose concentrations have been documented previously 
Table I. Physiochemical Properties of the Low Molecular Weight Proteins

\begin{tabular}{|c|c|c|c|c|c|}
\hline Protein & Isotype & Isoelectric point & & $\begin{array}{l}\text { Molecular } \\
\text { weight }\end{array}$ & $\begin{array}{l}\text { Molecular } \\
\text { form }\end{array}$ \\
\hline & & & & $D$ & $\% *$ \\
\hline \multirow[t]{3}{*}{ BJP1 } & $\kappa$ & $7.7,7.6$ & (Ma) & 21,600 & 45 \\
\hline & & $7.5,7.4,7.3$ & (Mi) & 42,170 & 46 \\
\hline & & & & 60,000 & 9 \\
\hline \multirow[t]{3}{*}{ BJP2 } & $\kappa$ & $7.2,6.9$ & (Ma) & 21,600 & 23 \\
\hline & & $6.8,6.7,6.6$ & (Mi) & 41,950 & 19 \\
\hline & & & & 74,100 & 58 \\
\hline \multirow[t]{3}{*}{ BJP3 } & $\lambda$ & $5.7,5.6$ & (Ma) & 14,800 & 46 \\
\hline & & $5.8,6.1,7.2,7.3$ & (Mi) & 22,500 & 32 \\
\hline & & & & 46,000 & 22 \\
\hline BLG & - & 5.1 & & 18,400 & 100 \\
\hline \multirow[t]{2}{*}{ MYG } & - & 7.3 & (Ma) & 16,950 & 100 \\
\hline & & $6.9,5.8$ & (Mi) & & \\
\hline
\end{tabular}

* Percent of the total amount of protein. Ma, major isoelectric points; $\mathrm{Mi}$, minor isoelectric points.

(4). Values obtained at the start and completion of the micropuncture period were averaged for each rat.

Microanalysis was performed using previously described techniques (4). The volume of fluid collected from the PT was measured using constant bore glass tubing and a microslide comparator (Gaertner Scientific Corp., Chicago, IL). Chloride concentrations of the perfusate and collectate samples were determined by electrometric titration (model FT-2230 microtitrator, W-P Instruments, Inc., New Haven, CT). Osmolalities of the nanoliter samples and perfusates were determined by freezing point depression (nanoliter osmometer; Clifton Technical Physics, Hartford, CT). The ${ }^{3} \mathrm{H}$ and ${ }^{14} \mathrm{C}$ activities of measured volumes of the collected samples and perfusate were determined using a liquid scintillation counter (model 6892; Tracor Analytic, Elk Grove Village, IL). In vivo microperfusion rate (PR), $J_{v}, J_{\mathrm{C}}$, and $J_{\mathrm{G}}$ were calculated using equations as described (4).
Statistical analysis. All values are represented as mean \pm SEM. Comparisons between experimental and corresponding control groups were analyzed for statistical significance by the unpaired, or paired $t$ test, where appropriate, with significance set at the $5 \%$ level.

\section{Results}

Physicochemical properties of the LMWPs. (Table I and Figs. 1 and 2) BJP1 was a $\kappa$ light chain (LC) that was present mostly in monomeric $(21,600 \mathrm{~mol} \mathrm{wt})$ and dimeric forms, with a small fraction as trimers; all of these forms resolved into one band after reduction. The two major $\mathrm{pI}$ were 7.7 and 7.6. BJP2 was also a $\kappa \mathrm{LC}$ that was composed of monomers $(21,600 \mathrm{~mol} \mathrm{wt})$, dimers, and high molecular weight forms. Under reducing conditions, the high molecular weight form was shown to consist of the LC plus a $51.7-\mathrm{kD}$ fraction that presumably represents a heavy chain. The major pIs of this protein were 7.2 and 6.9. BJP3 consisted of a $\lambda \mathrm{LC}$ of monomeric $(22,500 \mathrm{~mol} \mathrm{wt})$ and dimeric forms and a low molecular weight protein fragment $(14,800 \mathrm{~mol} \mathrm{wt})$ that reacted with antibody to $\lambda \mathrm{LC}$; the BJP also demonstrated microheterogeneity and had major pIs of 5.7 and 5.6. BLG had an $18,400 \mathrm{~mol} \mathrm{wt}$ and a $\mathrm{pI}$ of 5.1 . MYG had a 16,950 mol wt and a predominant pI of 7.3.

Systemic parameters. Mean systemic parameters of the 74 rats used in these studies were: hematocrit, $43 \pm 0.3 \%$; plasma sodium, $153 \pm 0.8 \mathrm{meq} / \mathrm{liter}$; plasma potassium, $4.4 \pm 0.0 \mathrm{meq} /$ liter; plasma chloride, $102 \pm 0.5 \mathrm{meq} /$ liter; plasma osmolality, $305 \pm 1 \mathrm{mosmol} / \mathrm{kg}$; plasma protein, $4.6 \pm 0.5 \mathrm{~g} / \mathrm{dl}$; and plasma glucose, $6.7 \pm 0.3 \mathrm{mmol} /$ liter. Average urine flow rate and inulin clearance were $13.4 \pm 1.6 \mu \mathrm{l} / \mathrm{min}$ per $100 \mathrm{~g} \mathrm{BW}$ and $1,018 \pm 35 \mu \mathrm{l} / \mathrm{min}$ per $100 \mathrm{~g} \mathrm{BW}$, respectively.

Proximal tubule studies. Mean calculated perfusion rates and lengths of the perfused segments of PT were not different between each experimental $(5 \mathrm{~g} / \mathrm{dl})$ and corresponding control groups (Table II). Perfusate osmolality and chloride concentrations were not different between control and experimental perfusions. PTs exposed to BJP1 or BLG for $20 \mathrm{~min}$ had decreased $J_{\mathrm{v}}, J_{\mathrm{Cl}}$ and $J_{\mathrm{G}}$ absorptions compared with controls (Table III). In contrast, no demonstrable alterations in PT

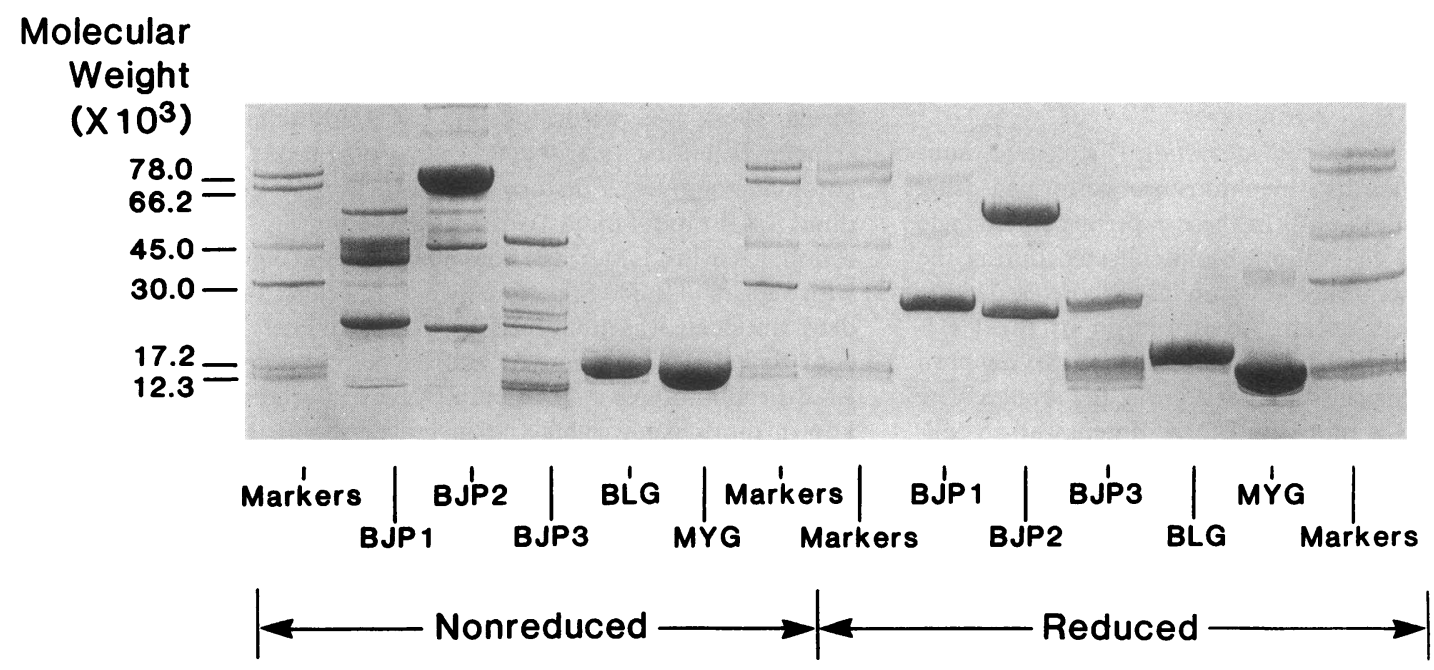

Figure 1. SDS-PAGE of the five proteins used. The left portion of the gel was run under nonreducing conditions, while the right portion was performed under reducing conditions. The standard proteins included: cytochrome $c(12,300 \mathrm{D})$, equine myoglobin $(17,200)$, carbonic anhydrase $(30,000)$, ovalbumin $(45,000)$, BSA $(66,250)$, and ovotransferrin $(78,000)$. 

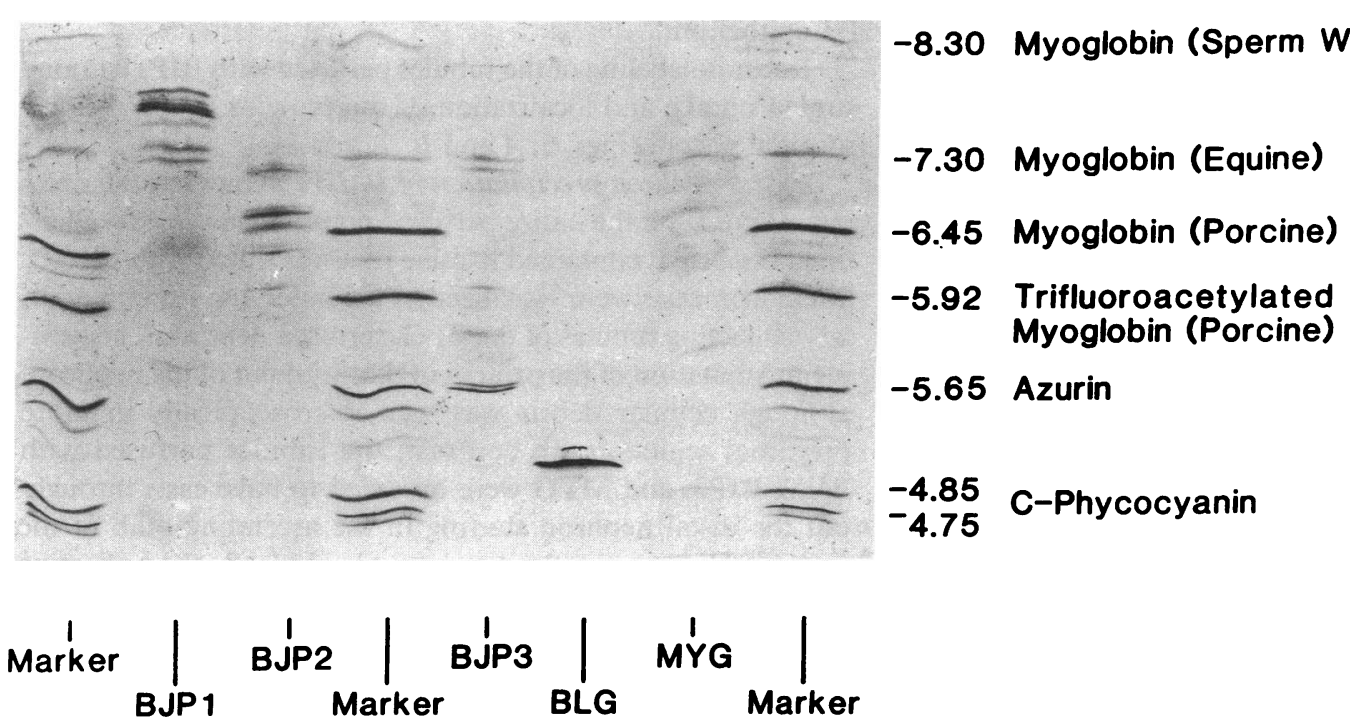

Figure 2. Isoelectric point determination of the five proteins, using Ampholine PAGplates, pH 3.5-9.5, with pI marker proteins that are shown.

function were seen after perfusion for $20 \mathrm{~min}$ with BJP2, BJP3, or MYG.

The effects of BJP1 at various concentrations on proximal tubule function is also shown (Fig. 3). The values were expressed as percent change from the corresponding control values. Mean perfusion rates, lengths of the perfused segments of PT, perfusate osmolality, and perfusate chloride concentrations were not different between experimental and control groups. Even at low concentrations $(0.01 \mathrm{~g} / \mathrm{dl})$, this protein manifested toxicity by diminishing volume, chloride, and glucose fluxes. Perfusion with BJP1, $0.001 \mathrm{~g} / \mathrm{dl}$, did not alter proximal tubule function.

In the morphologic studies, only those PTs that were ex-

Table II. Characteristics of the Perfusion Groups

\begin{tabular}{|c|c|c|c|}
\hline Group & $\begin{array}{l}\text { No. of } \\
\text { perfusions/rats }\end{array}$ & $\begin{array}{l}\text { Perfusion } \\
\text { rate }\end{array}$ & Tubule length \\
\hline & & $n l / \min$ & $\mathrm{mm}$ \\
\hline BJP1 & $16 / 6$ & $17.9 \pm 0.4$ & $2.6 \pm 0.2$ \\
\hline ATF1 & $13 / 5$ & $18.5 \pm 0.4$ & $2.7 \pm 0.4$ \\
\hline$P$ & & NS & NS \\
\hline BJP2 & $11 / 6$ & $17.9 \pm 0.8$ & $2.0 \pm 0.3$ \\
\hline ATF2 & $10 / 6$ & $18.2 \pm 0.5$ & $2.2 \pm 0.3$ \\
\hline$P$ & & NS & NS \\
\hline BJP3 & $15 / 9$ & $19.2 \pm 0.3$ & $1.9 \pm 0.2$ \\
\hline ATF3 & $16 / 8$ & $19.1 \pm 0.5$ & $1.9 \pm 0.2$ \\
\hline$P$ & & NS & NS \\
\hline BLG & $13 / 10$ & $18.2 \pm 0.3$ & $1.8 \pm 0.2$ \\
\hline ATF4 & $11 / 8$ & $18.9 \pm 0.6$ & $2.4 \pm 0.2$ \\
\hline$P$ & & NS & NS \\
\hline MYG & $8 / 7$ & $19.7 \pm 0.3$ & $1.8 \pm 0.1$ \\
\hline ATF5 & $9 / 6$ & $18.2 \pm 0.6$ & $1.6 \pm 0.3$ \\
\hline$P$ & & NS & NS \\
\hline
\end{tabular}

posed to BJP1 $(n=5)$ (Fig. 4) or to BLG $(n=4)$ (Fig. 5) demonstrated alterations in tubule ultrastructure that included focal loss of the microvillus border, vacuolation, and desquamation of cell fragments. There was activation of the lysosomal system and several of the lysosomes were distorted, markedly enlarged, and occasionally contained crystals (Fig. 6). In contrast, the ultrastructure of the PTs exposed to BJP2 $(n=2)$ (Fig. 7), BJP3 ( $n=3)$ (Fig. 8), and MYG $(n=3)$ (Fig. 9) was normal, except for focal loss of the microvillus border of one cell and rare vacuolation of the MYG-perfused tubules. The lysosomes of these perfused PTs were also activated but the distorted, atypical lysosomes were not present. Thus, the morphologic and functional data were complementary and

Table III. Absorption Characteristics of the Perfusion Groups

\begin{tabular}{lccc}
\hline Group & $\begin{array}{c}\text { Volume } \\
\text { absorption }\end{array}$ & $\begin{array}{c}\text { Chloride } \\
\text { absorption }\end{array}$ & $\begin{array}{c}\text { Glucose } \\
\text { absorption }\end{array}$ \\
\hline nl/min/mm & peq/min/mm & pmol/min/mm \\
BJP1 & $1.37 \pm 0.11$ & $138 \pm 16$ & $32 \pm 3$ \\
ATF1 & $2.30 \pm 0.27$ & $198 \pm 23$ & $44 \pm 4$ \\
$P$ & $<0.05$ & $<0.05$ & $<0.05$ \\
BJP2 & $1.76 \pm 0.22$ & $195 \pm 37$ & $37 \pm 3$ \\
ATF2 & $2.00 \pm 0.23$ & $179 \pm 20$ & $39 \pm 3$ \\
$P$ & $\mathrm{NS}$ & $\mathrm{NS}$ & $\mathrm{NS}$ \\
BJP3 & $1.62 \pm 0.32$ & $175 \pm 24$ & $38 \pm 4$ \\
ATF3 & $1.40 \pm 0.16$ & $145 \pm 16$ & $42 \pm 3$ \\
$P$ & $\mathrm{NS}$ & $\mathrm{NS}$ & $\mathrm{NS}$ \\
BLG & $1.29 \pm 0.14$ & $112 \pm 16$ & $28 \pm 2$ \\
ATF4 & $1.98 \pm 0.18$ & $164 \pm 19$ & $37 \pm 3$ \\
$P$ & $<0.05$ & $<0.05$ & $<0.05$ \\
MYG & $1.41 \pm 0.21$ & $164 \pm 49$ & $44 \pm 3$ \\
ATF5 & $1.48 \pm 0.29$ & $120 \pm 20$ & $36 \pm 5$ \\
$P$ & $\mathrm{NS}$ & $\mathrm{NS}$ & $\mathrm{NS}$ \\
\hline
\end{tabular}


BJP1, g/dl

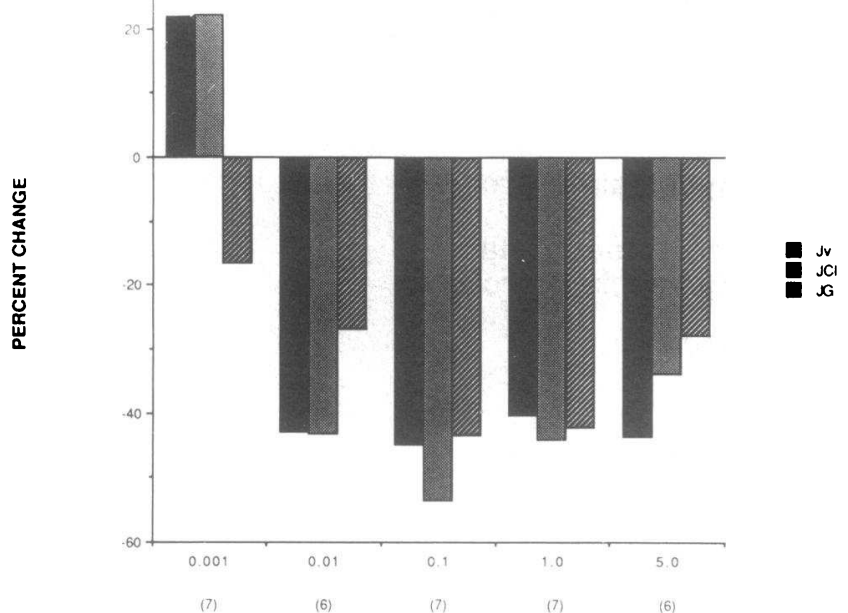

Figure 3. Effects of perfusion of proximal tubules with BJP1 in various concentrations. Toxicity that manifested as decreases in volume, chloride and glucose fluxes $(P<0.05)$ occurred even at low concentrations $(0.01 \mathrm{~g} / \mathrm{dl})$. Fluxes of control and BJP1, $0.001 \mathrm{~g} / \mathrm{dl}$, perfusions were not significantly different. The numbers in parentheses represent the number of observations for each group.

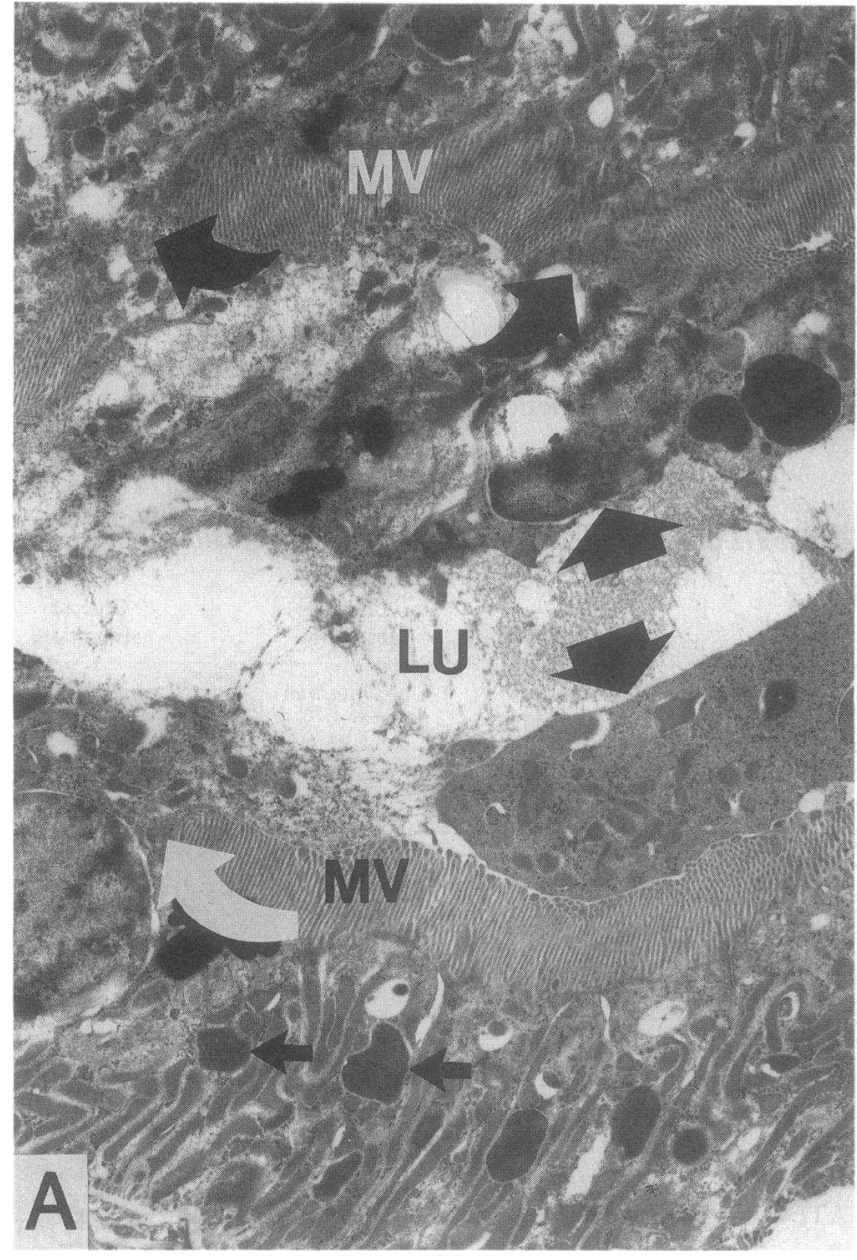

Figure 4. Electron micrographs of the proximal and distal tubules of a nephron perfused with BJP1. $(A)$ The PT demonstrated damage to the lining cells as manifested by focal loss of the microvillus border (MV) (curved arrows) and its lumen (LU) filled with cellular fragments (large arrows). The lysosomal system of the PT cells was acti- showed that only two LMWPs, BJP1 and BLG, damaged the PT epithelium.

Immunolabeling of the tubules perfused with BJPs demonstrated uptake and localization of the proteins in the endolysosomal system (Figs. 6, $A$ and $B$, 7, and 8).

Distal nephron precipitation of LMWP. Under the dissecting microscope, the entire perfused nephron was readily identified because it contained fixative that was tinted with FD\&C. Small firm casts were visualized in the outer and inner medullary collecting tubules of the BLG-perfused nephrons, suggesting precipitation of the protein in that segment of the nephron, although cellular debris was seen microscopically in more proximal segments. In contrast, the tubules perfused with BJP2, BJP3, and MYG were observed to have casts throughout the distal nephron starting in the ascending limb of the loop of Henle or early distal tubule. Indeed, the collecting tubule of one of the MYG-perfused nephrons was sectioned and a well-organized and dense cast that filled the lumen was easily removed. Casts of this nature were not seen with the dissecting microscope in the BJP1-perfused tubules.

The ultrastructure of the distal nephron of the perfused tubules was also examined. The distal nephrons of two BJP1perfused (Fig. 4) and three BLG-perfused tubules were filled with cellular elements (Fig. 5); of the other distal nephrons of

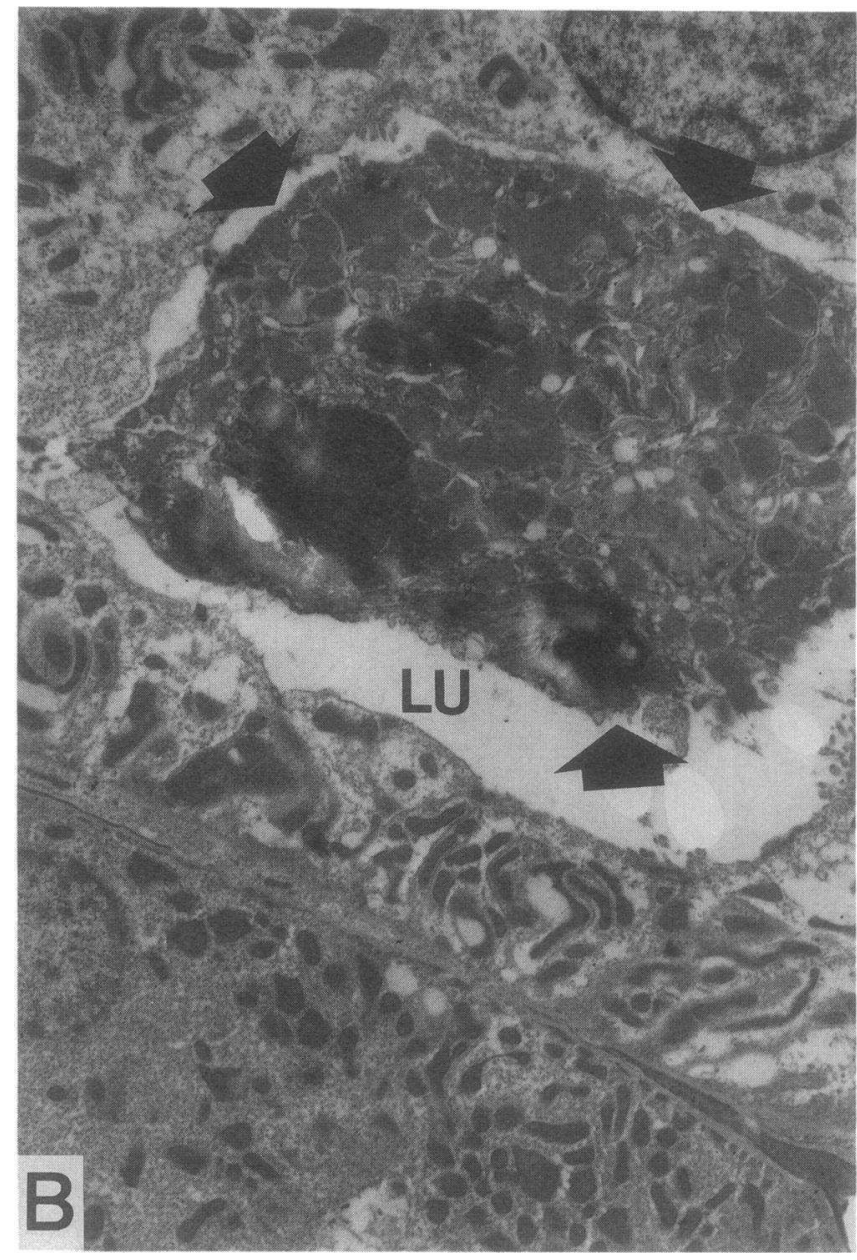

vated and some lysosomes appeared atypical (small arrows) (uranyl acetate and lead citrate, original magnification $\times 3,500)$. $(B)$ The lumen (LU) of the distal tubule was filled with cellular fragments (original magnification 3,500). 

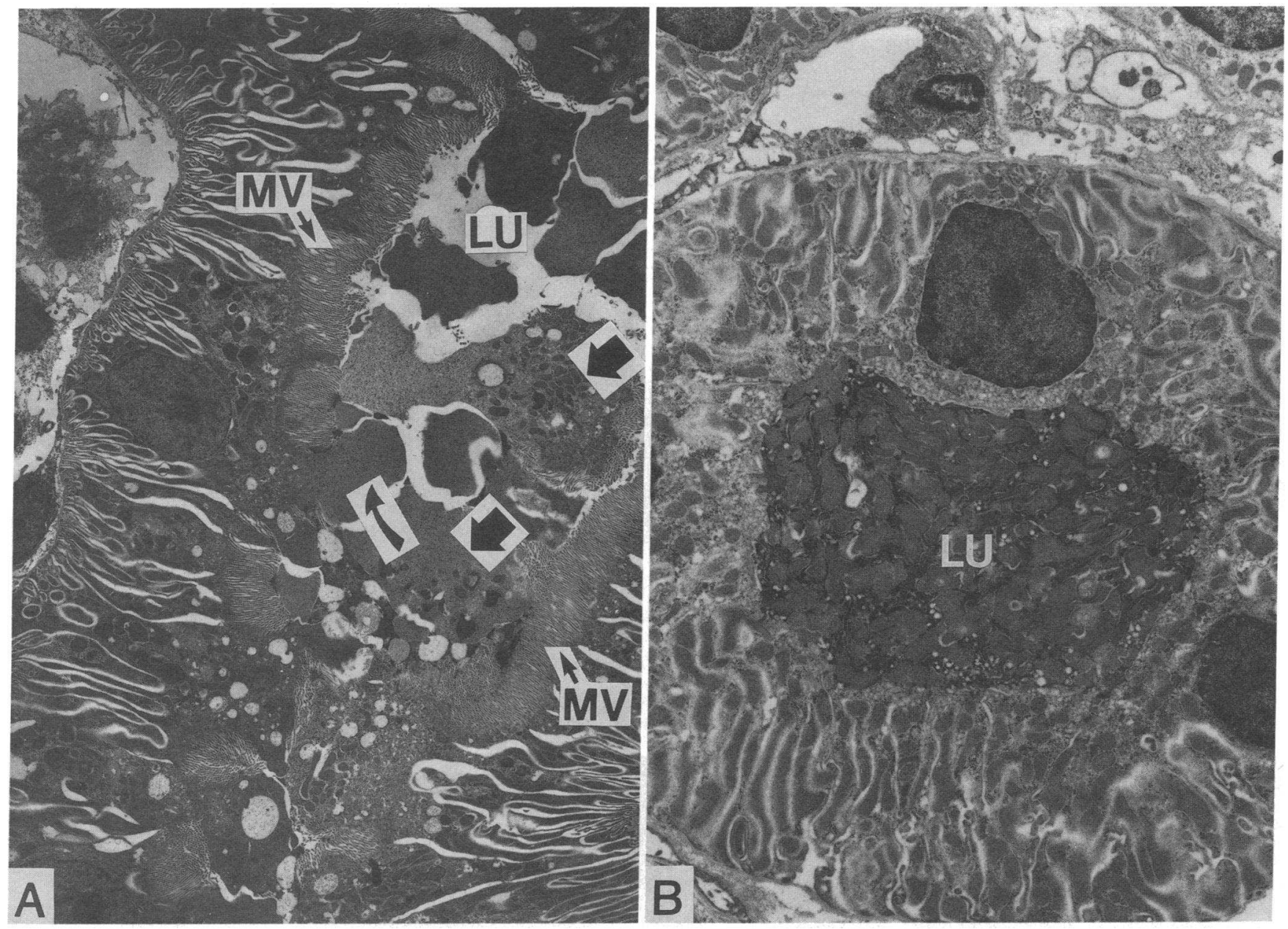

Figure 5. Electron micrographs of the proximal and distal tubules of a nephron perfused with BLG. $(A)$ This PT was damaged, as manifested by loss of the microvillus border (MV) (curved arrow) and cytoplasmic debris (straight arrows) in the lumen (LU) (original magnification 2,500). $(B)$ The lumen of this distal tubule contained cytoplasmic cellular elements (original magnification 3,500).

the BJP1-perfused tubules, one was patent and two could not be identified. In contrast, the distal nephrons of those tubules exposed to BJP2 (Fig. 7), BJP3 (Fig. 8), and MYG (Fig. 9) were filled with acellular casts.

\section{Discussion}

These functional and morphologic data complement each other and show that: $(a)$ some, but not all, LMWPs produced epithelial cell toxicity in the PT of the rat; $(b)$ some LMWPs, including BJP and MYG, precipitated in the distal lumen where they may produce intratubular obstruction; $(c)$ these mechanisms of tubule injury occurred independently; and (d) physicochemical properties of LMWPs, including pI, molecular form, and isotype (BJP), did not appear to be major factors associated with epithelial cell toxicity, although the four proteins with pIs less than 7.4 precipitated in the distal nephron.

Previous studies have demonstrated that LMWPs, such as BJPs (3, 4, 6, 7, 10-17), MYG (7, 18-21), lysozyme (22), and BLG $(6,7)$, can cause renal damage in humans and animals. Although most of these studies have shown a tubulointerstitial lesion $(3,4,6,10-12,13-18,20-23)$, other abnormalities including alterations in intrarenal hemodynamics $(19,21)$ and glomerular damage $(19,22)$ may also participate in the pathogenesis of renal failure from these proteins. Thus, in the investigation of the pathogenesis of the tubular nephrotoxicity of LMWPs, microperfusion of the nephron circumvents the confounding variables of the intrarenal vasculature and glomeruli, which can also alter the protein load to the tubules.

Direct PT cell injury, intraluminal precipitation of the protein and subsequent nephron obstruction, or a combination of these processes have been proposed as pathogenetic mechanisms of the tubulointerstitial renal lesion of BJPs (15). Previously, we have shown that both mechanisms may be involved in the nephrotoxicity of BJPs $(4,6)$; the current series have expanded these observations by demonstrating that they occurred independently of each other and with LMWPs other than BJPs. Only two of the proteins produced toxicity, while the other three proteins did not alter PT structure or function. For BJP1, toxicity has been shown previously to develop in a time-dependent fashion (4). In this study, toxicity also occurred with concentrations of BJP1 as low as $0.01 \mathrm{~g} / \mathrm{dl}$, but not $0.001 \mathrm{~g} / \mathrm{dl}$ (Fig. 3). In addition, one of the five proteins did not precipitate in the distal nephron. Thus, neither PT damage nor distal nephron precipitation were nonspecific manifestations of perfusion with the LMWPs. Both epithelial cell toxicity and precipitation of LMWPs in the distal tubule were selective 

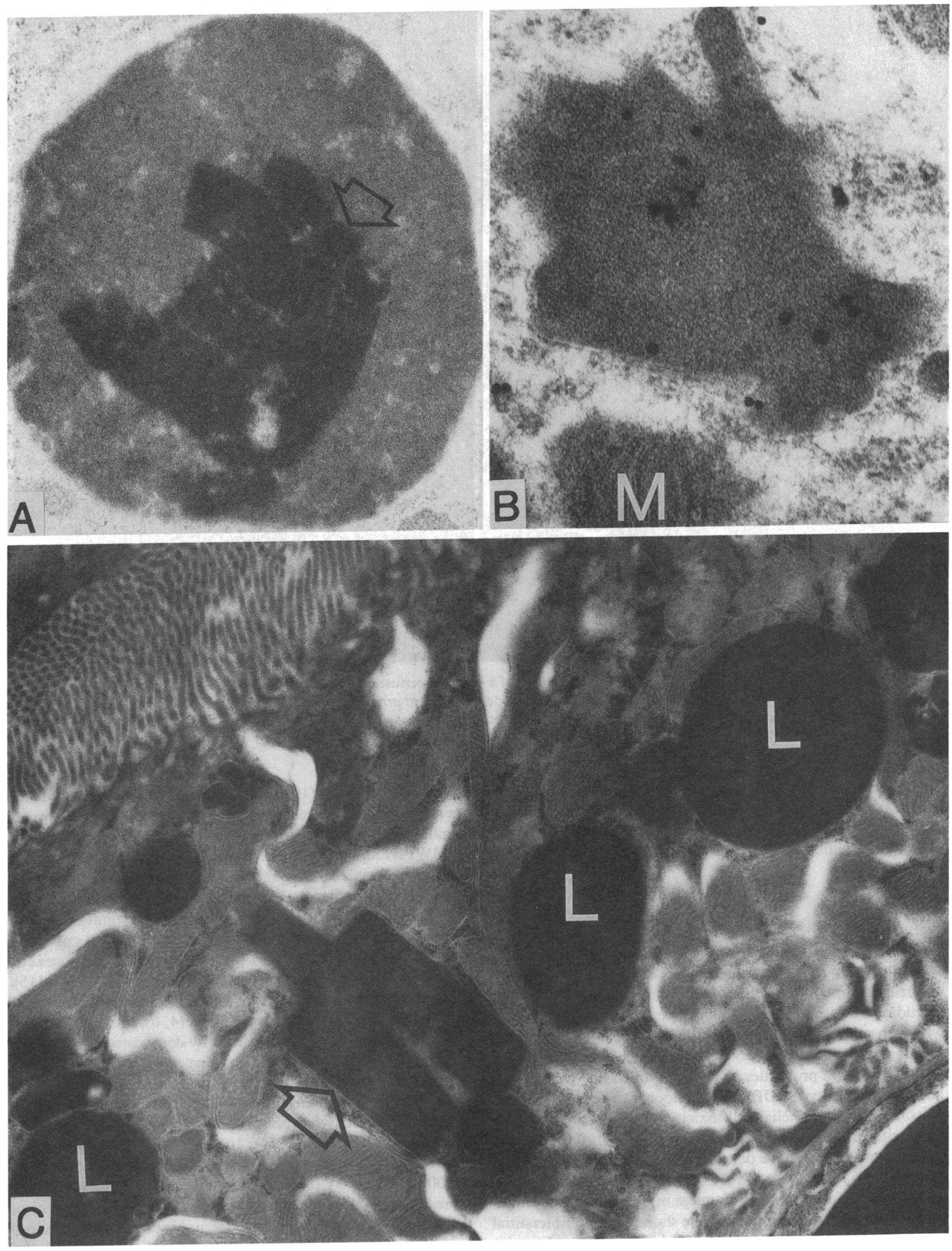

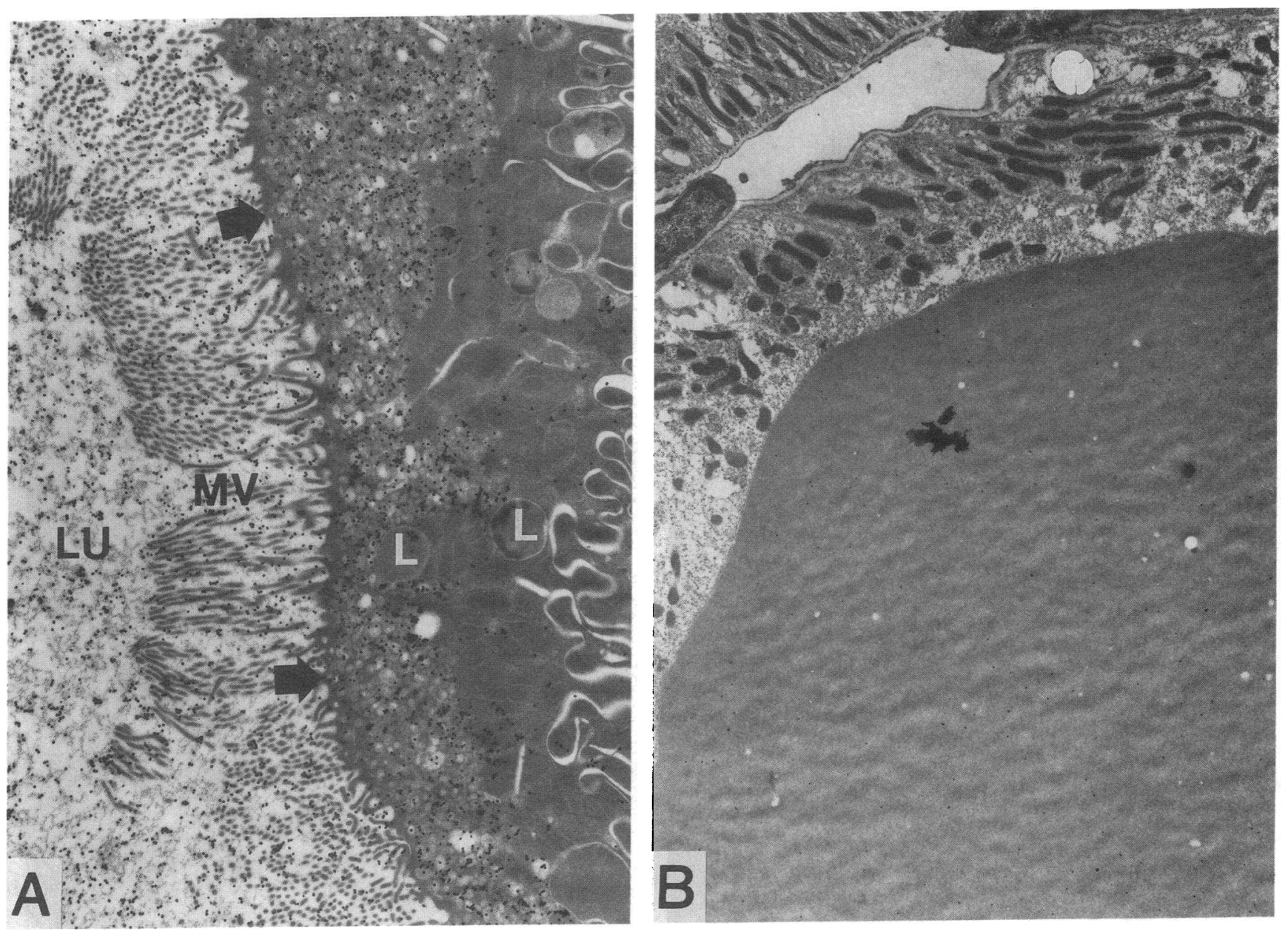

Figure 7. Immunoelectron micrographs of the proximal and distal tubules of a nephron perfused with BJP2. $(A)$ The morphology of the PT was normal despite the marked endocytosis of the protein into the endosomes (arrows) and lysosomes $(\mathrm{L})$. The microvillus border (MV) was intact (original magnification 5,000). (B) The distal nephron was filled with an acellular cast (original magnification 1,500).

processes that appear to be related to distinctive, as yet undetermined, physicochemical property(s) of the LMWPs.

Several studies have produced conflicting results regarding correlation between nephrotoxicity and isoelectric point of LMWPs. While some authors have suggested that the $\mathrm{pI}$ of the protein is an important nephrotoxic property in humans $(20$, 24) and in animal models of cast nephropathy (10) and cell toxicity (25), others have not been able to reproduce these results $(6,16,17,26,27)$. A reason for this confusion is that, as we have demonstrated, LMWPs can produce two distinct tubular lesions, PT injury and intrarenal obstruction, and these lesions were not considered separately by most of these investigators. Our current studies show that the pI of a LMWP was not a major determinant of cell toxicity since proteins with pIs of 5.1 and 7.7 were toxic, while those LMWPs with pIs between these values were nontoxic.

Intranephronal precipitation did occur, however, with per- fusion with those proteins that had pIs $<7.4$. This observation contradicts Clyne and associates (10), who suggested a correlation between nephrotoxicity of BJPs and higher pI. One difference between their study and ours was the route of administration of the protein. They gave the proteins intraperitoneally, while we infused the proteins directly into the nephron. Thus, glomerular sieving of the proteins was avoided in our study, but serves as a confounding variable in their study because only dimeric forms of the BJPs were used. The pI of the dimer favors glomerular filtration of the more cationic proteins of this size and would therefore variably alter the load of the proteins presented to the tubule. Another difference is that their study did not consider the two independent mechanisms of BJP-induced tubule damage since they examined the tissue primarily for the presence of casts. With the dissecting microscope, we also noted that those LMWPs with pIs between 5.6 and 7.3 precipitated in the ascending limb of the loop of Henle
Figure 6. Lysosomes of cells of PTs exposed to BJP1 or BLG. $(A)$ Several lysosomes contained crystals (arrow) (original magnification $25,000)$. (B) Some lysosomes were very atypical, as demonstrated here. These lysosomes have been labeled utilizing an indirect immunogold procedure with antibody to $\kappa$ light chain, which is repre- sented by the black dots. Mitochondria (M) and other cytoplasmic elements did not label (original magnification 50,000). $(C$ ) Several lysosomes (L) of the PT exposed to BLG appeared atypical and some contained crystals (arrow) (original magnification 8,000). 


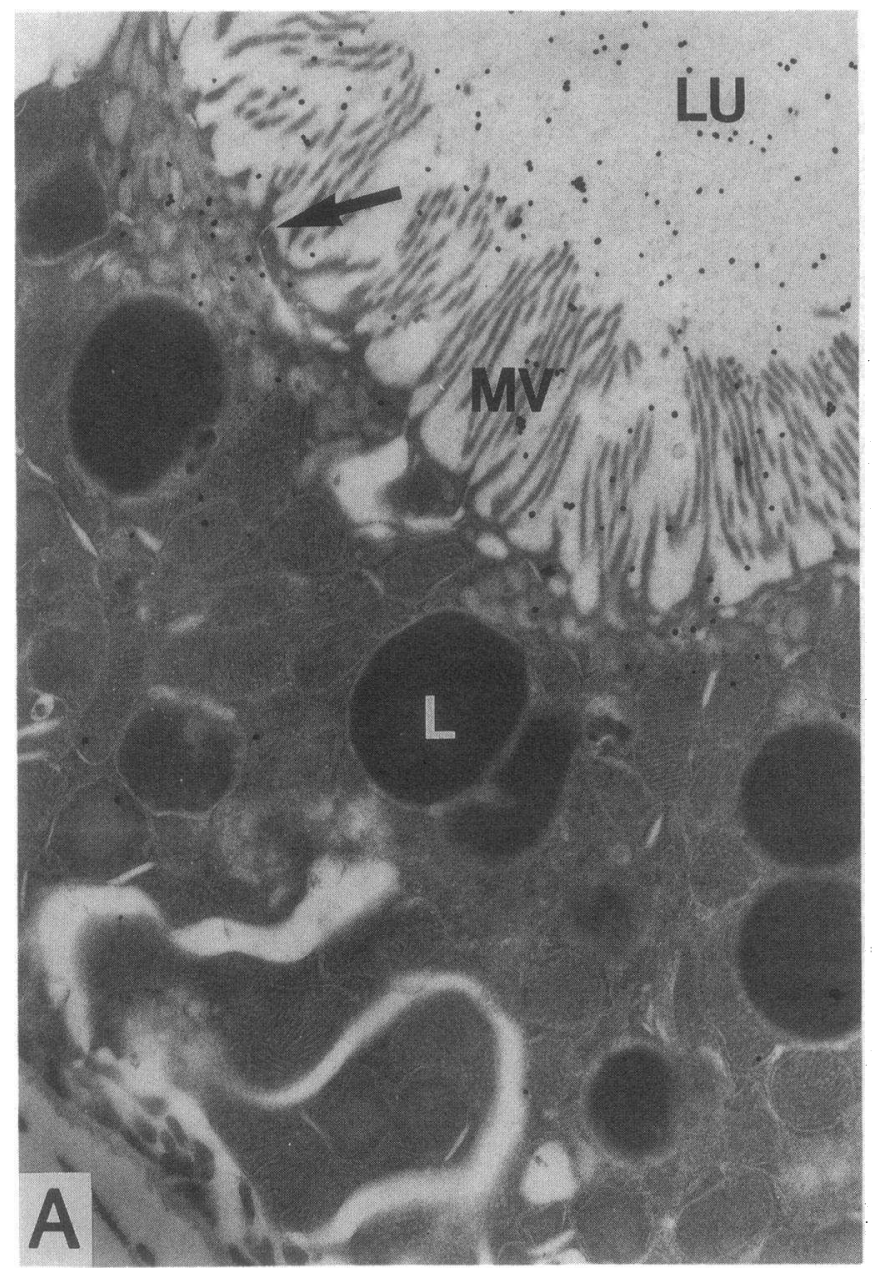

Figure 8. Immunoelectron micrographs of the proximal and distal tubules of a nephron perfused with BJP3. $(A)$ The PT was normal in appearance except for activation of the lysosomal system (L); the microvillus border (MV) was intact. Absorption of the $\lambda \mathrm{LC}$ (black dots)

or distal tubule, whereas BLG, which has a pI of 5.1, tended to precipitate later in the nephron (6). These data suggest that during the normal process of acidification of the tubule fluid, the tubule fluid $\mathrm{pH}$ approaches the $\mathrm{pI}$ of these proteins and facilitates their precipitation (28), which may be accentuated by the presence of Tamm-Horsfall protein (20) and lower fluid flow rates in the distal nephron. Thus, a $\mathrm{pI}<7.4$ may be a major but not the sole factor causing distal nephron cast formation.

Other physicochemical properties, such as isotype of the BJPs and molecular form, have not been shown clinically to correlate with nephrotoxicity (26). In agreement with these observations, we showed that both $\kappa$ and $\lambda$ BJPs can be nephrotoxic, producing either toxicity or acellular casts. A particular molecular form did not confer (or prevent) toxicity since BLG existed only in monomeric form, while BJP1, the other toxic protein, was composed of monomers, dimers and trimers. Distal nephron precipitation of the LMWPs also did not correlate with either of these properties. The high molecular weight form of BJP2 represented a heavy chain attached to the light chain; because it was excreted in the urine of the patient, it was included in the BJP2 protein. Although this high molecular weight form may have contributed to the cast for-

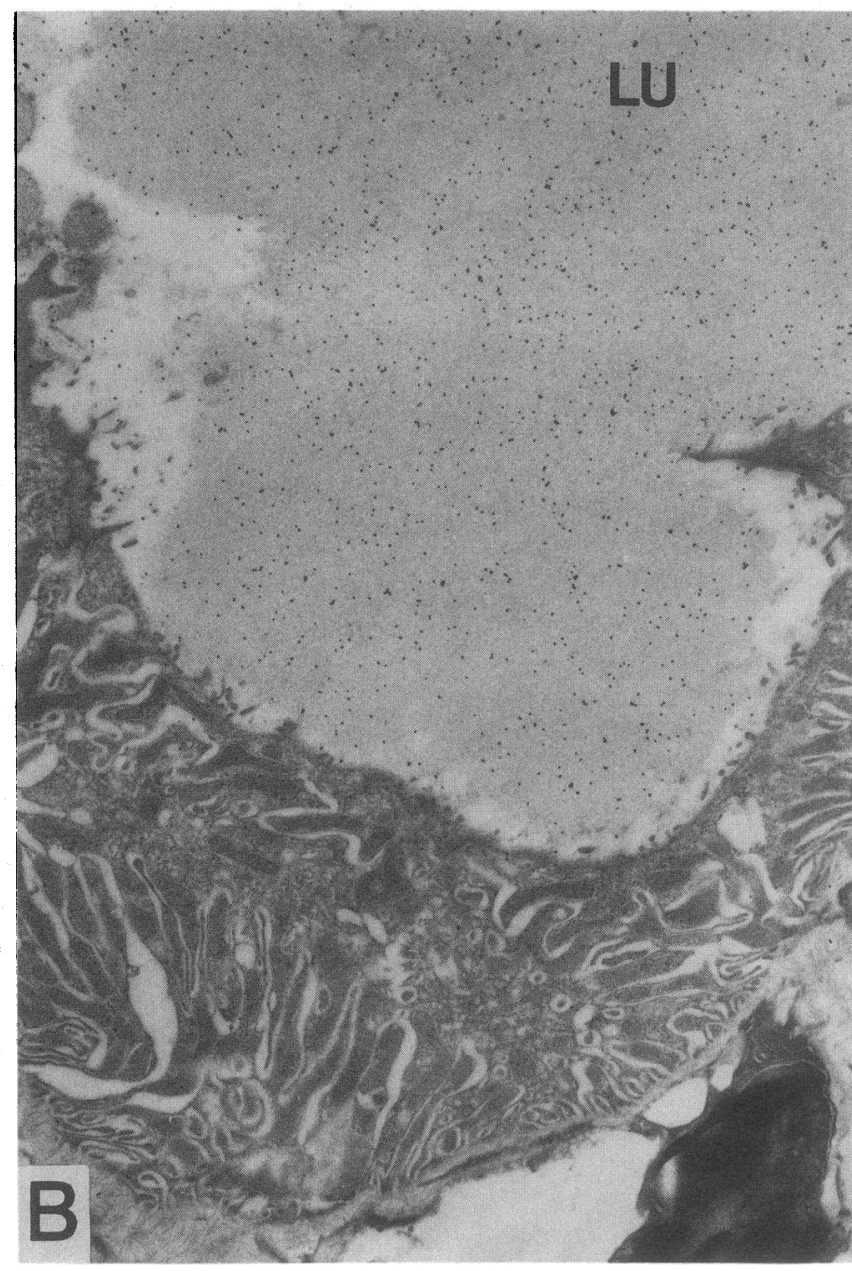

(arrow) was demonstrated (original magnification 8,000). (B) The distal nephron was filled with acellular material that contained the protein (black dots) (original magnification 3,500).

mation that was seen with perfusion with that protein, cast formation also occurred with BJP3, BLG, and MYG. Therefore, neither isotype nor molecular form were important factors influencing nephrotoxicity in our test system.

How LMWPs are toxic to the cells of the PT is not well defined. We have previously suggested that deranged lysosomal processing of certain BJPs may subsequently produce epithelial cell injury $(3,4)$. Some BJPs precipitate in the presence of lysosomal enzymes and an acidic environment (29); this tendency to precipitate could alter lysosomal function, which may eventually result in lysosomal rupture, cell damage, and cell death in some instances. Those tubules exposed to the toxic LMWPs (BJP1 and BLG) also had very atypical, distorted lysosomes with some containing crystalline-like structures (Fig. 6). These data suggest that deranged lysosomal function from certain proteins may be involved in the pathogenesis of epithelial cell toxicity. Although variable absorption of the BJPs may account for PT cell toxicity, Smolens et al. (30), have shown no significant differences in absorption of three rat light chains with different pIs in rat PT in vivo.

The glycerol model of acute renal failure has a complicated pathophysiology that includes formation of casts of MYG, intravascular volume depletion and altered intrarenal hemo- 

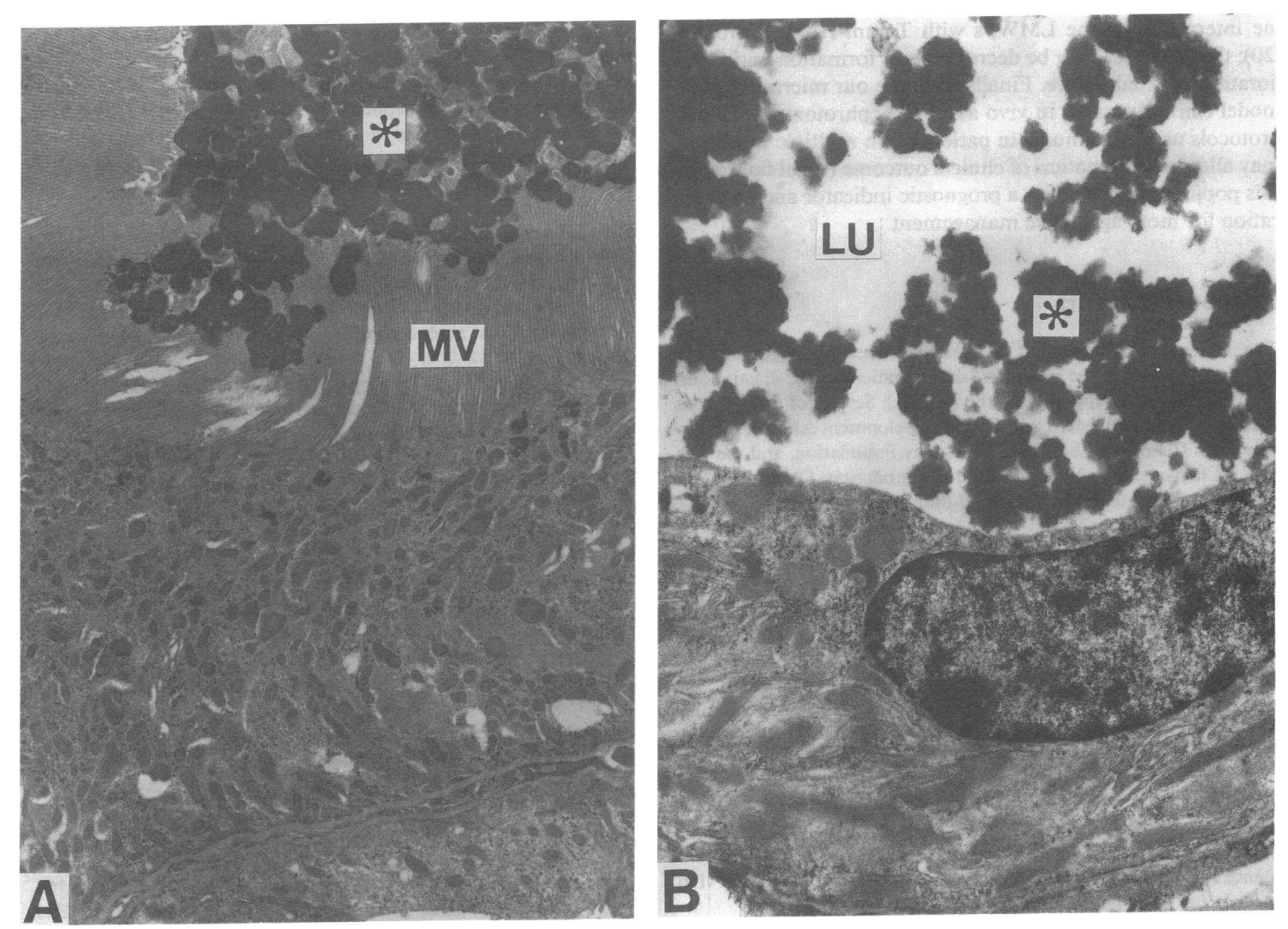

Figure 9. Electron micrographs of the proximal and distal tubules of a nephron perfused with MYG. $(A)$ The PT was normal in appearance with a preserved microvillus border (MV) and the lumen contained MYG (asterisk) (original magnification 3,500). (B) The lumen (LU) of the distal nephron was filled with MYG (asterisk) (original magnification 6,000).

dynamics; these latter factors also directly affect tubule function and make definitive conclusions regarding tubule injury difficult (18-21). While the functional role of intratubular precipitation of MYG has been questioned (19), Mason et al. (23) have demonstrated correlations among intratubular pressure elevation, oliguria, and intraluminal cast formation after intravenous injection of methemoglobin. In addition, Cushner and associates (18) have shown that acute volume expansion elevates intratubular pressures in those kidneys exposed to MYG. On the other hand, chronic volume expansion in this model ameliorates the fall in inulin clearance and decreases the degree of cast formation by MYG without altering PT necrosis (18). We have demonstrated that MYG is not acutely toxic to the PT, but precipitates and occludes the distal nephron. Taken together with these other reports, our findings strongly suggest an important role of tubule obstruction in the pathogenesis of MYG-induced acute renal failure; acute proximal tubule injury did not appear to relate to myoglobin directly and was not required for MYG to precipitate in the lumen of the distal nephron.

To the extent that these observations may be translated to humans, it appears that either PT toxicity or distal nephron obstruction or both can occur in the setting of low molecular weight proteinuria. Patients with BJP may present with PT damage or distal nephron casts, alone or in concert $(3,11,12)$. This PT lesion (3) closely resembles that shown with perfusion of rat tubules with human BJP and results from absorption of the light chain into the PT cells and apparent lysosomal derangement, which produces cell death $(3,4)$. In some instances, renal failure may be due to PT injury plus intranephronal obstruction from sloughing of cell fragments that lodge in the distal nephron. In our series, a particular pl, isotype, or molecular form did not correlate with toxicity.

Distal nephron precipitation of the LMWP may be the initial event in the production of the chronic tubulointerstitial lesion ("myeloma kidney") of multiple myeloma. Once the nephron is damaged from persistent obstruction, the integrity of lining epithelium and the tubular basement membrane is subsequently lost, allowing leak of tubule fluid and protein into the interstitium. The extravasated tubule fluid can then serve as a nidus to promote the interstitial reaction and giant cell formation.

Our studies, which demonstrated precipitation in the distal nephron of those BJPs and MYG that had pIs $<7.4$, also provide a rationale for alkalinization of the urine in the setting of myoglobinuria or Bence Jones proteinuria (7) since this maneuver may increase tubule fluid $\mathrm{pH}$, facilitating solubilization of these LMWPs in the distal tubule and also decreasing 
the interaction of the LMWPs with Tamm-Horsfall protein (20); the net effect may be decreased cast formation and amelioration of renal failure. Finally, because our microperfusion model can serve as an in vivo assay of nephrotoxicity, future protocols using this model in patients with multiple myeloma may allow determination of clinical outcome (renal failure) in this population, providing a prognostic indicator and an indication for more aggressive management.

\section{Acknowledgments}

The authors thank Dr. Robert G. Luke for his helpful suggestions and the Media Service of the Veterans Administration for the illustrations.

This work was supported by the Research Service of the Veterans Administration with Merit and Career Development Awards, the Birmingham Chapter of the Alabama Kidney Foundation, and the Alabama Chapter of the National Kidney Foundation. Dr. Sanders is a Research Associate of the Veterans Administration.

\section{References}

1. Carone, F. A., D. R. Peterson, S. Oparil, and T. N. Pullman. 1979. Renal tubular transport and catabolism of proteins and peptides. Kidney Int. 16:271-278.

2. Maack, T., V. Johnson, S. T. Kau, J. Figueiredo, and D. Sigulem. 1979. Renal filtration, transport, and metabolism of low-molecularweight proteins: A review. Kidney Int. 16:251-270.

3. Sanders, P. W., G. A. Herrera, and J. H. Galla. 1988. Morphologic alterations of the proximal tubules in light chain-related renal disease. Kidney Int. 33:881-889.

4. Sanders, P. W., G. A. Herrera, and J. H. Galla. 1987. Human Bence Jones protein toxicity in rat proximal tubule epithelium in vivo. Kidney Int. 32:851-861.

5. Sanders, P. W., J. E. Volanakis, S. G. Rostand, and J. H. Galla. 1986. Human complement protein D catabolism by the rat kidney. $J$. Clin. Invest. 77:1299-1304.

6. Weiss, J. H., R. H. Williams, J. H. Galla, J. L. Gottschall, E. D. Rees, D. Bhathena, and R. G. Luke. 1981. Pathophysiology of acute Bence-Jones protein nephrotoxicity in the rat. Kidney Int. 20:198-210.

7. Holland, M. D., J. H. Galla, P. W. Sanders, and R. G. Luke. 1985. Effect of urinary $\mathrm{pH}$ and diatrizoate on Bence Jones protein nephrotoxicity in the rat. Kidney Int. 27:46-50.

8. Herrera, G. A., E. A. Turbat-Herrera, G. Viale, P. dell'Orto, R. L. Lott, R. Columbi, R. W. Alexander, and G. Coggi. 1987. Ultrastructural immunolabeling in renal diseases. Past, present, and future expectations. Pathol. Immunopathol. Res. 6:51-63.

9. Görg, A., W. Postel, J. Weser, H. W. Schiwara, and W. H. Boesken. 1985. Horizontal SDS electrophoresis in ultrathin pore-gradient gels for the analysis of urinary proteins. Science Tools. 32:5-10.

10. Clyne, D. H., A. J. Pesce, and R. E. Thompson. 1979. Nephrotoxicity of Bence Jones proteins in the rat: Importance of protein isoelectric point. Kidney Int. 16:345-352.

11. DeFronzo, R. A., C. R. Cooke, J. R. Wright, and R. L. Humphrey. 1978. Renal function in patients with multiple myeloma. Medicine (Baltimore). 57:151-166.

12. DeFronzo, R. A., R. L. Humphrey, J. R. Wright, and C. R.
Cooke. 1975. Acute renal failure in multiple myeloma. Medicine (Baltimore). 54:209-223.

13. Koss, M. N., C. L. Pirani, and E. F. Osserman. 1976. Experimental Bence Jones cast nephropathy. Lab. Invest. 34:579-591.

14. McIntire, K. R., and M. Potter. 1964. Studies of thirty different Bence Jones protein-producing plasma cell neoplasms in an inbred strain of mouse. J. Natl. Cancer Inst. 33:631-648.

15. Pirani, C. L., F. G. Silva, and G. B. Appel. 1983. Tubulo-interstitial disease in multiple myeloma and other nonrenal neoplasias. In Tubulo-interstitial Nephropathies. R. S. Cotran, B. M. Brenner, and J. H. Stein, editors. Churchill Livingstone, New York. 287-334.

16. Smolens, P., M. Venkatachalam, and J. H. Stein. 1983. Myeloma kidney cast nephropathy in a rat model of multiple myeloma. Kidney Int. 24:192-204.

17. Smolens, P., J. L. Barnes, and J. H. Stein. 1986. Effect of chronic administration of different Bence Jones proteins on rat kidney. Kidney Int. 30:874-882.

18. Cushner, H. M., J. L. Barnes, J. H. Stein, and H. J. Reineck. 1986. Role of volume depletion in the glycerol model of acute renal failure. Am. J. Physiol. 250 (Renal Fluid Electrolyte Physiol. 19):F315-F321.

19. Hostetter, T. H., B. M. Wilkes, and B. M. Brenner. 1980. Mechanisms of impaired glomerular filtration in acute renal failure. In Acute Renal Failure. B. M. Brenner and J. H. Stein, editors. Churchill Livingstone, New York. 68-73.

20. Pesce, A. J., D. H. Clyne, V. E. Pollak, and S. K. Kant. 1980. Renal tubular interactions of proteins. Clin. Biochem. 13:209-215.

21. Ruiz-Guinazu, A., J. B. Coelho, and R. A. Paz. 1967. Methemoglobin-induced acute renal failure in the rat. Nephron. 4:257-275.

22. Cojocel, C., N. Dociu, and K. Baumann. 1982. Early nephrotoxicity at high plasma concentrations of lysozyme in the rat. Lab. Invest. 46:149-157.

23. Mason, J., C. Olbricht, T. Takabatake, and K. Thurau. 1977. The early phase of experimental acute renal failure. I. Intratubular pressure and obstruction. Pfluegers Arch. Eur. Physiol. 370:155-163.

24. Coward, R. A., I. W. Delamore, N. P. Mallick, and E. L. Robinson. 1984. The importance of urinary immunoglobulin light chain isoelectric point (pI) in nephrotoxicity in multiple myeloma. Clin. Sci. 66:229-232.

25. Park, C. H., and T. Maack. 1984. Albumin absorption and catabolism by isolated perfused proximal convoluted tubules of the rabbit. J. Clin. Invest. 73:767-777.

26. Johns, E. A., R. Turner, E. H. Cooper, and I. C. M. Maclennan. 1986. Isoelectric points of urinary light chains in myelomatosis. Analysis in relation to nephrotoxicity. J. Clin. Pathol. 39:833-837.

27. Rota, S., B. Mougenot, B. Baudouin, M. De Meyer-Brasseur, V. LeMaitre, C. Michel, F. Mignon, E. Rondeau, P. Vanhille, P. Verroust, and P. Ronco. 1987. Multiple myeloma and severe renal failure: a clinicopathologic study of outcome and prognosis in 34 patients. Medicine (Baltimore). 66:126-137.

28. Lehninger, A. L. 1975. Proteins: Purification and characterization. In Biochemistry. Worth Publishers, Inc., New York. 157-182.

29. Tan, M., and W. Epstein. 1972. Polymer formation during the degradation of human light chain and Bence-Jones proteins by an extract of the lysosomal fraction of normal human kidney. Immunochemistry. 9:9-16.

30. Smolens, P., and V. Miller. 1987. Renal tubular uptake of light chains (LC) of different isoelectric points (pI). Xth International Congress of Nephrology Abstract. 591. 